\author{
ks. Stanistaw Garnczarski \\ Wydziat Teologiczny Sekcja w Tarnowie \\ Uniwersytet Papieski Jana Pawta II w Krakowie
}

\title{
Pieśni mszalne ks. Franciszka Walczyńskiego
}

\section{Wykaz skrótów}

KiKM (1865)

Kiliń (1862)

Klon1 (1867)

- Kancyonat i ksiażka modlitewna na caty rok. Do nabożeństwa kościelnego i domowego, druk i nakł. K. Prochaska, Cieszyn 1865.

- Śpiewy nabożne dla użytku katolików archidyecezyi gnieźnieńskiej i poznañskiej, zebr. i wyd. ks. T. Kiliński, kanonik przy kolegiacie św. Maryi Magdaleny w Poznaniu, Poznań 1862.

- Szczeble do nieba, czyli zbiór pieśni z melodyjami w Kościele rzymsko-katolickim od najdawniejszych czasów użyanych, uskuteczniony przez Teofila Klonowskiego nauczyciela przy Król. katol. naucz. Seminarium w Poznaniu, t. 1, Poznań 1867.

$\mathrm{KMiK}(1830) \quad-$ Książka modlitewna i kancjonat, Opole 1830.

Kun (1859) - Pieśni kościelne dla mtodzieży szkót gimnazyalnych [...] wydat Tomasz Kunzek, Lwów 1859.

Maz1 (1867) - J. Mazurowski, Melodie do zbioru pieśni nabożnych katolickich do użytku kościelnego. Utożone do grania na organach i śpiewania na cztery gtosy, Pelplin 1871.

Miod1 (1838) - Śpiewnik Kościelny czyli pieśni nabożne z melodyjami w kościele katolickim używane a dla wygody kościotów parafialnych przez X. M. M. Mioduszewskiego Zgrom. XX. Miss. zebrane, Kraków [1838]; Dodatki: 1842, 1849, 1853.

OZ (1866) - Ottarz ztoty czyli zbiór nabożeństwa dla chrzéscian katolików z przydatkiem pieśni nabożnych dla użytku wiernych utożony, druk i nakł. J. Cotta, Warszawa 1866. 
PCCiC (1858) - Praca codzienna, coroczna i catożywotna każdego chrzescianina katolickiego; albo: ksiażka modlitewna i kancyonat dla katolików, z różnych książek modlitewnych iśpiewników zebrana, Cieszyn 1858.

Rasz (1825)

- W. Raszek, Kancjonat muzyki kościelnej, Warszawa 1825.

SiedlJubil (1928) - J. Siedlecki, Śpiewnik kościelny. Wydanie jubileuszowe (1978-1928), oprac. W. Świerczek, B. Wallek-Walewski, Kraków [1928].

SiedlMłodz2 (1908) - Śpiewniczek zawierający pieśni kościelne z melodyami dla użytku mtodzieży szkolnej przezx. J. Siedleckiego zebrany a przez Wysoka c.k. Radę Szkolna krajowa uchwata zdnia 14 lipca 1880 L. 556 dla szkót ludowych, pospolitych $i$ wydziatowych przeznaczony, Kraków 1908.

St. A (1586) - Cancional Piosnek rozmaitych, Staniątki 1586.

ŚKdMł (1858) - Śpiewy kościelne dla mtodzieży, druk i nakł. J. Pokorna, Wadowice 1858.

ŚKdMSz1 (1861) - Śpiewnik kościelny dla mtodzieży szkolnej, czcionkami K. Budweisera, Kraków 1861.

ŚKdMSz2 (1863) - Śpiewnik kościelny dla mtodzieży szkolnej z polecenia przewielebnego Księdza St. O.D. i P.W. wydany, Bochnia 1863.

ŚQC (1802)

Walcz4 (1931)

- [P. Folwarski], Śpiewnik „Qui cantat bis orat”, Kraków 1802.

- F. Walczyński, Nowe melodje do starych pieśni mszalnych w uktadzie dwugtosowym dla użytku mtodzieży szkolnej i chórów parafialnych, Tarnów 1931.

Walcz5 (1931) - F. Walczyński, Tekst pieśni mszalnych dla użytku mtodzieży szkolnej i chórów parafialnych, Tarnów 1931.

Wśród pieśni nabożnych istnieje szczególna ich grupa, a mianowicie pieśni mszalne. Siostra Bolesława Bielawska rozróżnia dwojakie ich rozumienie. W szerszym znaczeniu mamy na myśli pieśni, hymny, sekwencje stosowane w liturgii bez względu na ich treść i wewnętrzny związek z mszą świętą. W ścisłym znaczeniu należą do nich tylko cykle pieśni specjalnie układanych do wykonania przez lud w czasie mszy. Pieśni w tym drugim znaczeniu składają się przeważnie z dziewięciu części wzorowanych na Ordinanrium i Proprium missae i od nich zapożyczają swoje tytuły. Takie zestawy pieśni określono jako „pieśni mszalne” lub „msze polskie”.

1 B. Bielawska, Polska pieśń mszalna do 1914 roku, w: Studia z dziejów liturgii w Polsce, t. 3, red. W. Schenk, Lublin 1980, s. 119. 


\section{Ksiądz Franciszek Walczyński $i$ jego sylwetka}

Diecezja tarnowska w swojej ponad 225-letniej historii może się poszczycić kilkoma wybitnymi postaciami osób duchownych działających na polu muzyki religijnej. Wśród nich jedno z czołowych miejsc zajmuje ks. Franciszek Walczyński (ur. 20 grudnia 1852 r. w Żywcu - zm. 12 lipca 1937 r. w Tarnowie) ${ }^{2}$. W tym roku przypada zatem 80 . rocznica jego śmierci. W dziedzinie muzyki był autodydaktą, czyli samoukiem, co wskazuje w świetle jego dorobku artystycznego na ogromny talent muzyczny. W swojej młodości pobierał co prawda prywatne lekcje z muzyki, ale była to jedyna forma edukacji z nauczycielem. W późniejszych latach studium muzyczne prowadził już sam, poprzez lekturę podręczników, książek oraz nut, których posiadał dużą ilość. Jako kapłan wiele podróżował, odwiedzając ośrodki muzyczne w Berlinie, Wiedniu, Monachium, Pradze i Ratyzbonie ${ }^{3}$. Duszpastersko pracował w Limanowej (jeden rok), a później przy tarnowskiej katedrze, gdzie był również opiekunem i dyrygentem chóru katedralnego. Od tego momentu jego życie związało się z Tarnowem już do końca. Po latach pełnienia funkcji wikariusza w katedrze pracował jako katecheta I Gimnazjum, uczył w Instytucie SS. Urszulanek, w Seminarium Duchownym, gdzie prowadził także chór klerycki ${ }^{4}$. Był wreszcie współzałożycielem Towarzystwa ku wspieraniu muzyki kościelnej pw. św. Wojciecha, w ramach którego prowadził chór oraz uczył w szkole organistów diecezji tarnowskiej. Jego działalność popularyzatorską, edukacyjną czy wychowawczą przewyższała jednakże aktywność na polu kompozycji. W jego twórczości muzycznej wyróżnić można trzy nurty: pieśni jednogłosowej, utworów chóralnych oraz kompozycji organowych. Poza kilkoma utworami jest to twórczość wyłącznie religijna. Do niej należy zaliczyć także wiele opracowań funkcjonujących już pieśni na chóry, zarówno mieszane, jak i jednorodne oraz przygotowanie towarzyszeń organowych do pieśni oprócz utworów samodzielnych. Skomponował też wiele mszy oraz jedno oratorium na Boże Narodzenie. Wydał pod swoją redakcją, a częściowo też autorstwem śpiewnik - w $1884 \mathrm{r}^{5}$, wznowiony i poszerzony w roku $1910^{6}$. Podsumowując to krótkie i z konieczności bardzo pobieżne ukazanie sylwetki ks. Franciszka Walczyńskiego, należy podkreślić, że jego spuścizna kompozytorska jest ogromna, ponieważ liczy ok. 230 utworów, z tego ok. 200 wokalnych.

2 A. Nowak, Walczyński Franciszek, w: Stownik polskich teologów katolickich 1918-1981, t. 6, red. L. Grzebień, Warszawa 1983, s. 362.

3 W. Orzech, Dziatalność kościelno-muzyczna ks. Infutata Franciszka Walczyńskiego, Odbitka z dwumiesięcznika „Chór Parafialny”, Przemyśl 1938, s. 6.

4 W. Orzech, Dziatalność kościelno-muzyczna..., dz. cyt.

5 F. Walczyński, Śpiewnik kościelny, Tarnów 1884.

6 F. Walczyński, Śpiewnik kościelny, Tarnów 1910. 


\section{Początki pieśni mszalnych}

O początkach polskiej pieśni religijnej pisało już wielu, między innymi także autor niniejszego opracowania ${ }^{7}$, dlatego po krótkim wstępie przejdziemy od razu do nakreślenia początków pieśni mszalnych w ścisłym tego słowa znaczeniu. Już w XIII w. język polski pojawił się w liturgii mszalnej na polecenie ówczesnych synodów. Arcybiskup Pełka na synodzie prowincji gnieźnieńskiej we Wrocławiu w 1248 r. postanowił, by kapłani odmawiali z ludem w każdą niedzielę i święta po ewangelii Modlitwę Pańską i wyznanie wiary w języku ludowym (polskim). Arcybiskup Świnka ponownie wrócił do tej sprawy na synodzie w Łęczycy w roku 1285, nakazując, by po mszalnym Credo wykładano ludowi Wierzę, Ojcze nasz i Zdrowaś po polsku${ }^{8}$. Po opanowaniu wspólnej recytacji wymienionych tekstów zaczęto je śpiewać, gdyż w tej formie lud lepiej zapamiętywał prawdy wiary i utrwalał je w swojej świadomości. Świadectwem, że można je wykonywać na melodię Deka$\log u^{9}$, są liczne wzmianki przy późniejszych pieśniach. Z praktyki śpiewu pieśni kazaniowych i katechizmowych rozwinęła się późniejsza praktyka śpiewu innych pieśni w języku polskim w czasie celebracji mszy świętej. Były to pieśni okresowe śpiewane przy kazaniach (wielkanocne ${ }^{10}$, na Zesłanie Ducha Świętego ${ }^{11}$, bożonarodzeniowe ${ }^{12}$ czy adwentowe ${ }^{13}$ ). Z czasem pojawiają się pieśni, przy których zostały wskazane momenty celebracji liturgicznej, w których należy je wykonywać, np. „Powythay dzyewicze czyalo kthoresz na krzyzu wiszyalo trzeczyego dnya zmartwych wsthalo sthoba panno krolowlo nawyeki”, przy której zanotowano: „przed przyjęciem ciała pańskiego śpiewywana" ${ }^{14}$; Wspominając Boże stowa o siedmiu słowach Pana Jezusa na krzyżu, z adnotacją „po podniesieniu” ${ }^{15}$; Witaj Jezu przenastodszy z notką: „po Elewaciey osobliwa pyosnka”, czyli po podniesieniu ${ }^{16}$. W ten sposób

7 S. Garnczarski, Początki polskiej pieśni kościelnej i jej tematyka, „Tarnowskie Studia Teologiczne" 35 (2016) nr 1, s. 177-187.

8 H. Feicht, Studia nad muzyką polskiego średniowiecza, Kraków 1975, s. 378.

9 H. Feicht, Studia nad muzyką..., dz. cyt., s. 379.

10 Tzw. tropy rezurekcyjne: Chrystus zmartwychwstat je i Przez twe święte zmartwychwstanie. Zob. B. Bielawska, Polska pieśń..., dz. cyt., s. 123.

11 Dusze, zawitaj k’nam. Zob. B. Bielawska, Polska pieśń..., dz.cyt.

12 Zdrów bądź, Królu anielski. Zob. B. Bielawska, Polska pieśń..., dz. cyt.

13 Postat przez anioty - tłumaczenie sekwencji Mittit ad Virginem, oraz Zdrowaś bądź Maryja - tłumaczenie tropu Ave Hierarchia. Por. S. Garnczarski, Polska pieśń adwentowa w drukach od XVII do XX wieku, Tarnów 2014, cz. 1, s. 270-271, 280-281.

14 B. Bielawska, Polska pieśń..., dz. cyt., s. 126.

15 B. Bielawska, Polska pieśń..., dz. cyt.

16 St. A (1586). B. Bielawska, Polska pieśń..., dz. cyt. 
lud brał coraz bardziej aktywny udział w liturgii, czerpiąc ze śpiewanych pieśni treści wprowadzające go w jakimś stopniu w głębię obrzędu, któremu towarzyszyły. Były to początki polskiej pieśni mszalnej. W późniejszym okresie powstały z nich pełne polskie msze. Najstarszą znaną pieśnią mszalną w ścisłym tego słowa znaczeniu jest Kirie, Oycze taskawy ${ }^{17}$. Składa się z pięciu części: Kirie, Gloria, Credo, Elevatia i Agnus. W brakujących częściach odwołuje się do innych pieśni, podając ich tytuły. Kirie posiada swoją własną melodię. Gloria może być - według wskazówki zamieszczonej na końcu - wykonywane na melodie wymienionych pieśni okresowych (w Adwencie brano melodię z pieśni adwentowej Urząd Zbawienia, na Boże Narodzenie - Dzieciątko się narodzito itd. Pieśń nie zawiera własnej pieśni Po Epistole, ale wskazuje na dwie inne do wyboru: Racz strzedz nasz panie lub Maria Matko mitości. Credo posiada własną melodię. Na Ofertorium przewidziano pieśń Do ciebie Panie lub inną odpowiednią pieśń roku liturgicznego. Na Sanctus podane są suplikacje. Na Elevacia jest pieśń adoracyjna Boga w Świętym Sacramencie na melodię Przed tak wielkim Sacramentem. Na Agnus śpiewa się trzyzwrotkową pieśń Baranku Boży. Na Ite Missa należy pięć razy śpiewać Ktorys dla nas cierpiat rany Jezu Christe zmituj się nad nami. Amen ${ }^{18}$. Jak widać, na omawianą mszę lub pieśń mszalną składają się pieśni specjalnie do niej ułożone oraz tradycyjne pieśni nabożne. Zestaw ten jest przejściem do pełnych pieśni mszalnych, posiadających własne teksty na wszystkie stałe i zmienne części mszy ${ }^{19}$.

\section{Pieśni mszalne Franciszka Walczyńskiego}

Powyższym określeniem zostały objęte pieśni mszalne zawarte w broszurce Nowe melodje do starych pieśni mszalnych... ${ }^{20}$ wydanej w Tarnowie w $1931 \mathrm{r}$. przez ks. Franciszka Walczyńskiego. Zawiera ona osiem utworów. Są one opracowane na dwa głosy i przeznaczone dla młodzieży szkolnej oraz chórów para-

17 Zamieszczona w zestawie: Sposób śpiewania polskiego na mszach, wklejonym w drugiej części dużego rękopiśmiennego zbioru modlitw, litanii i pieśni ks. Franciszka Walentego Ruthena, proboszcza z Kłodawy. Zob. Bibl. Kórnicka, sygn. 40: Pars secunda Cantionalis [...] per Franciscum Valentinum Ruthen. Sposób śpiewania znajduje się na s. 451-465. Por. R. Marciniak, M. Muszyński, J. Wiesiołowski, Katalog rękopisów staropolskich Biblioteki Kórnickiej XVIXVIII w., t. 1, Wrocław 1971, s. 98.

18 B. Bielawska, Polska pieśń..., dz. cyt., s. 135-137.

19 B. Bielawska, Polska pieśń..., dz. cyt., s. 137.

20 Walcz4 (1931). Należy jeszcze dodać, iż w tym samym roku ukazał się w kieszonkowym formacie śpiewniczek z samymi tylko tekstami pieśni mszalnych: F. Walczyński, Tekst pieśni mszalnych dla użytku mtodzieży szkolnej i chórów parafialnych, Tarnów 1931. Redaktor uznał, że młodzieży wystarczy zbiorek wyłącznie z tekstami. 
fialnych. Publikacja ukazała się nakładem autora oraz czcionkami Zygmunta Jelenia w Tarnowie. Jak sam tytuł wskazuje, omawiane pieśni mszalne zaczerpnięte zostały ze zbioru już używanych, natomiast ich teksty w opracowaniu Walczyńskiego opatrzono nowymi melodiami. Należy tu zaznaczyć, iż na ówczesnym etapie rozwoju pieśni mszalnych były to cykle opatrzone jedną melodią, stosowaną w każdej z części mszy, w przeciwieństwie do etapu początkowego, w którym poszczególne części posiadały różne melodie. Tak więc spotykamy tu następujące pieśni mszalne:

1. Boże, lud Twój

2. Nieogarniony

3. Panie! Stwórco nieba, ziemi

4. Przed tronem Twym upadamy

5. W tej światyni zgromadzeni

6. Przedziwna Matko

7. Boże, Sędzio sprawiedliwy

8. Tobie, Boże, wznosim pienia

Pieśni te składają się najczęściej z dziewięciu części: Introit, Gloria, Graduat, Credo, Ofertorium, Sanctus, Benedictus, Agnus i Ite missa. W tym układzie określamy je - według Bielawskiej - jako pełny zestaw. Spotykamy też cykle o mniejszej liczbie części, jak np. osiem, siedem czy sześć. Ponieważ wiele pieśni mszalnych powstało anonimowo i trudno jest dzisiaj ustalić ich autorów, dlatego w dalszych badaniach będziemy wymieniać zbiory, w których dana pieśń pojawiła się po raz pierwszy. Takie ujęcie wskazuje na możliwość istnienia badanego śpiewu wcześniej niż datowany jest zbiór zawierający go.

Niektóre części pieśni mszalnych u Walczyńskiego różnią się nieco między sobą określeniami, a mianowicie: zamiast Introit spotykamy $\mathrm{Na}$ Confiteor, zamiast Graduat widnieje Ewangelija oraz zamiast Benedictus funkcjonuje Po Podniesieniu.

Niektóre pieśni mszalne mają określone swoje szczególne przeznaczenie, jak Przedziwna Matko - w uroczystości maryjne, czy Boże, Sędzio sprawiedliwy i Tobie, Boże, wznosim pienia - za dusze zmarłych.

\section{Źródta pieśni}

Ustalenie autorów badanych utworów jest trudne, ze względu na brak danych. Jednakże - jak już wyżej powiedziano - wskazanie zbiorów, w których - według obecnych ustaleń - pojawiają się po raz pierwszy, może w jakimś stopniu określić czas ich powstania. Ponadto $\mathrm{w}$ niniejszym opracowaniu badane śpiewy zostaną pokazane też w innych źródłach, czasowo bliskich najstarszym, i będa wzajemnie porównane. 
Boże, lud Twój-pojawia się w Kancjonale ${ }^{21}$ Wacława Raszka wydanym w 1825 r. Autor publikacji wiąże pieśni mszalne w niej zawarte z poszczególnymi świętami czy też okresami liturgicznymi. Powyższą pieśń przyporządkował świętom wielkanocnym. Wydaje się, że połączenie to jest mechaniczne i sztuczne, nieuwzględniające treści śpiewu. Pieśń ta znajduje się także w zbiorach: Kun $(1859)^{22}$, SiedlMłodz $(1908)^{23}$ i SiedlJubil $(1928)^{24}$. Jak widać, udało się ją znaleźć tylko w jednym źródle XIX-wiecznym oraz w dwóch XX-wiecznych.

Pieśń mszalna Nieogarniony - po raz pierwszy pojawia się w Śpiewniku ks. Marcina Michała Mioduszewskiego ${ }^{25}$, chociaż można spotkać przekazy ${ }^{26}$ mówiące o tym, że śpiewana była już w latach dwudziestych XIX w. W innych źródłach XIX-wiecznych pojawia się dosyć często: OZ $(1866)^{27}$, KiKM $(1865)^{28}$, ŚKdMSz $z_{2}(1863)^{29}$, Kiliń $(1862)^{30}$, ŚKdMSz $z_{1}(1861)^{31}$, ŚKdMł $(1858)^{32}$, PCCiC $(1858)^{33}$.

Panie! Stwórco nieba, ziemi - swoje źródło ma w zbiorze Teofila Klonowskiego Szczeble do nieba ${ }^{34}$. Poszczególne jej części są krótkie, jednozwrotkowe, a jedynie komunia posiada dwie, w których bardzo zwięźle oddaje treść tekstów mszalnych.

Przed tronem Twym upadamy - występuje w zbiorze ks. Józefa Mazurowskiego Zbiór pieśni nabożnych ${ }^{35}$. W innych źródłach nie została ustalona.

Pieśń W tej świątyni zgromadzeni - znajdujemy w Dodatku ${ }^{36}$ do Śpiewnika Mioduszewskiego oraz w OZ (1866) ${ }^{37}$.

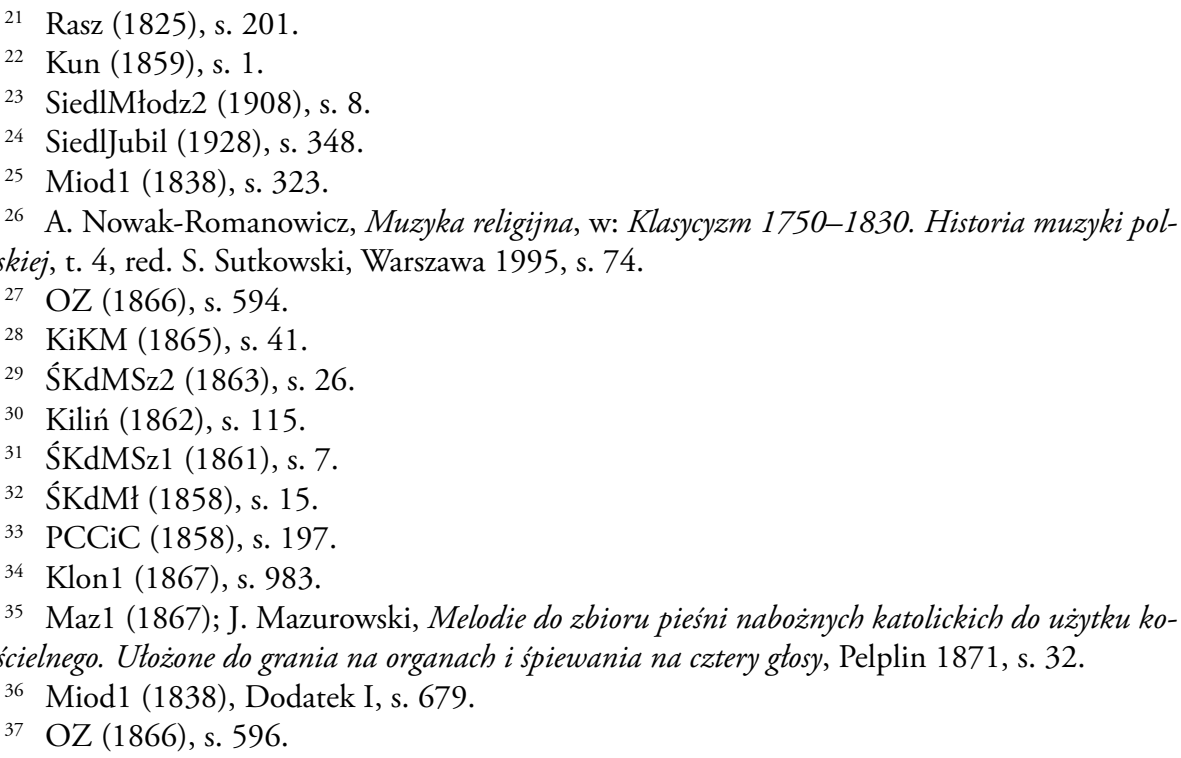


Przedziwna Matko - pojawia się jedynie w Dodatku II ${ }^{38}$ do Śpiewnika Mioduszewskiego.

Boże, Sędzio sprawiedliwy - spotkana po raz pierwszy w źródłach w latach trzydziestych XIX w., czego przykładem jest Ksiązka modlitewna $i$ kancjona ${ }^{39}$. Ponadto zamieszczona jest także w następujących źródłach: OZ $(1866)^{40}$, KiKM $(1865)^{41}$ oraz Kiliń $(1862)^{42}$.

Pieśń Tobie, Boże, wznosim pienia spotykamy pierwszy raz w Dodatku I ${ }^{43}$ do Śpiewnika Mioduszewskiego oraz w dwóch późniejszych źródłach: KiKM $(1865)^{44}$ i OZ $(1866)^{45}$.

\section{Teksty}

Pod względem warstwy tekstowej ks. Walczyński przejął pieśni z innych źródeł. Zostały one powyżej zaprezentowane. $\mathrm{O}$ tym, czy istniały jeszcze inne zbiory, do których dzisiaj nie dotarliśmy, dowiemy się, badając i porównując teksty. Poniżej zostaną przeanalizowane: podział pieśni na części, warianty tekstów oraz ich struktura poetycka.

\section{Podziat pieśni na części i warianty tekstowe}

Określiliśmy powyżej, za Bielawską, układ dziewięcioczęściowy jako „pełny zestaw". Wśród badanych śpiewów w opracowaniu Walczyńskiego znajdujemy cztery utwory dziewięcioczęściowe - Boże, lud Twój ${ }^{46}$; Nieogarniony ${ }^{47}$; Przed tronem Twym upadamy ${ }^{48}$ oraz $W$ tej świątyni zgromadzeni ${ }^{49}$. Ośmioma częściami cechują się także dwie kolejne pieśni, mianowicie: Panie! Stwórco nieba, zie$m i^{50}$ oraz Przedziwna Matko ${ }^{51}$. Po jednej pieści reprezentuje układ siedmioczę-

\footnotetext{
Miod1 (1838), Dodatek II, s. 937.

KMiK (1830).

OZ (1866), s. 629.

KiKM (1865), s. 20.

Kiliń (1862), s. 123.

Miod1 (1838), Dodatek I, s. 690.

$44 \mathrm{KiKM}$ (1865), s. 63.

45 OZ (1866), s. 632.

46 Walcz5 (1931), s. 3.

47 Walcz5 (1931), s. 5.

48 Walcz5 (1931), s. 10.

49 Walcz5 (1931), s. 13.

50 Walcz5 (1931), s. 8.

51 Walcz5 (1931), s. 16.
} 
ściowy - Boże, Sędzio sprawiedliwy ${ }^{52}$, oraz układ sześcioczęściowy - Tobie, Boże, wznosim pienia ${ }^{53}$.

W układzie ośmioczęściowym brakuje części Graduat (Panie! Stwórco nieba, ziemi) lub Ite missa est (Przedziwna Matko). Układ siedmioczęściowy charakteryzuje się brakiem Gloria i Credo (Boże, Sędzio sprawiedliwy). Liczący najmniej, bo sześć części układ nie zawiera: Gloria, Credo i Ite missa est (Tobie, Boże, wznosim pienia). Ostatnie dwie pieśni, o siedmio- i sześcioczęściowej budowie, przeznaczone są za zmarłych, stąd zapewne brak Gloria i Credo.

Ciekawą rzeczą jest, że w badanych śpiewach oraz tych wcześniejszych nie występuje śpiew na Komunię św. Pojawia się on dopiero w późniejszych źródłach. W tekstach używanych przez ks. Walczyńskiego nie występuje w ogóle. Można stąd wnioskować, że korzystał on z najstarszych wersji pieśni, które w późniejszym okresie rozwoju pieśni mszalnych były uzupełniane nowymi częściami. Przykładowo w pieśni Boże, lud Twój w zbiorze Kun (1859) znajdujemy pełny zestaw części, czyli dziewięć, uzupełniony o część Komunia św., co czyni go nadkompletnym względem najstarszych wersji pieśni mszalnych. W okresie pełnego rozwoju omawianych pieśni można by ten dziesięcioczęściowy zestaw uznać za układ kompletny. Ta część pojawia się także w śpiewie Panie! Stwórco nieba, ziemi w zbiorze $\mathrm{Klon}_{2}$ (1867), z tym że jej budowa była ośmioczęściowa, w sumie daje więc teraz dziewięć części.

Prowadząc badania porównawcze, możemy stwierdzić, że w niektórych źródłach ta sama pieśń posiada różną liczbę części. W pieśni Boże, lud Twój w zbiorze SiedlJubil (1928) opuszczono dwie części: Ewangelja i drugą strofę z części Po Podniesieniu. Pieśń Nieogarniony w śpiewniku ŚKdMSz ${ }_{1}$ (1861) nie posiada trzech części: Gloria, Ewangelia i Credo. W zbiorze Klon 2 (1867) w pieśni Panie, Stwórco nieba pominięto część Podniesienie.

Oprócz omówionych wyżej różnic w podziale pieśni na części wyznaczone przez określone obrzędy mszy świętej spotykamy też różnice w samych tekstach. Polegają one z jednej strony na dodaniu lub pominięciu strof w poszczególnych częściach albo z drugiej strony na różnicach w analogicznych dla siebie zwrotkach. Przykładem pierwszych są trzy pieśni: Przedziwna Matko - tab. 1, Tobie, Boże, wznosim pienia - tab. 2, oraz Panie! Stwórco nieba, ziemi - tab. 3.

52 Walcz5 (1931), s. 19.

53 Walcz5 (1931), s. 21. 
Tabela 1

\begin{tabular}{|c|c|}
\hline Walcz $_{5}(1931)$ & $\operatorname{Miod}_{1}(1838)$ \\
\hline Introit - Początek mszy św. & \\
\hline Przedziwna Matko Słowa wcielonego, & Przedziwna Matko Słowa wcielonego, \\
\hline Tyś wielbień naszych dziś celem, & Tyś wielbień naszych dziś celem, \\
\hline Kiedy pamiątkę ${ }^{* * *}$ Twego & Kiedy pamiątkę *** Twego \\
\hline Obchodzi Kościół z weselem; & Obchodzi Kościół z weselem; \\
\hline Przyjmij więc od nas, któreć wznosim pienia, & Przyjmij więc od nas, któreć wznosim pienia, \\
\hline Ku czci i chwale Twojego Imienia, & Ku czci i chwale Twojego Imienia, \\
\hline Marjo czysta Dziewico! & Marjo czysta Dziewico! \\
\hline- & Tyś się nam stała wszystkich cnót przykładem, \\
\hline- & Abyśmy z ciebie wzór brali, \\
\hline- & Kto Twoim wiernie postępuje śladem, \\
\hline- & Ten tylko godnie Cię chwali: \\
\hline- & Uproś nam Twoich cnót naśladowanie, \\
\hline- & Pokorę, czystość, Jezusa kochanie, \\
\hline- & O święta Panno Maryja. \\
\hline Gloria - Chwała na wysokości Bogu & \\
\hline Chwała Ci, Boże, niech będzie na niebie, & Chwała Ci, Boże, niech będzie na niebie, \\
\hline A pokój ludziom na ziemi, & A pokój ludziom na ziemi, \\
\hline Z całego serca uwielbiamy Ciebie, & $\mathrm{Z}$ całego serca uwielbiamy Ciebie, \\
\hline Sławimy głosy wspólnemi; & Sławimy głosy wspólnemi; \\
\hline Królu niebieski, Ojcze wszechmogący, & Królu niebieski, Ojcze wszechmogący, \\
\hline Boże przedwieczny, granic nieznający, & Boże przedwieczny, granic nieznający, \\
\hline Tobie dziś dzięki składamy. & Tobie dziś dzięki składamy. \\
\hline- & O Synu Boży u Ojca jedyny! \\
\hline- & O Jezu Chryste nasz Panie! \\
\hline- & Który całego gładzisz świata winy, \\
\hline- & Przyjmij to nasze błaganie: \\
\hline- & Boś Ty sam święty, sam najwyższym Panem, \\
\hline- & Wraz z Duchem Swiętym w szczęściu nieprzebranem, \\
\hline- & I w chwale Ojca Twojego. \\
\hline
\end{tabular}


Tabela 2

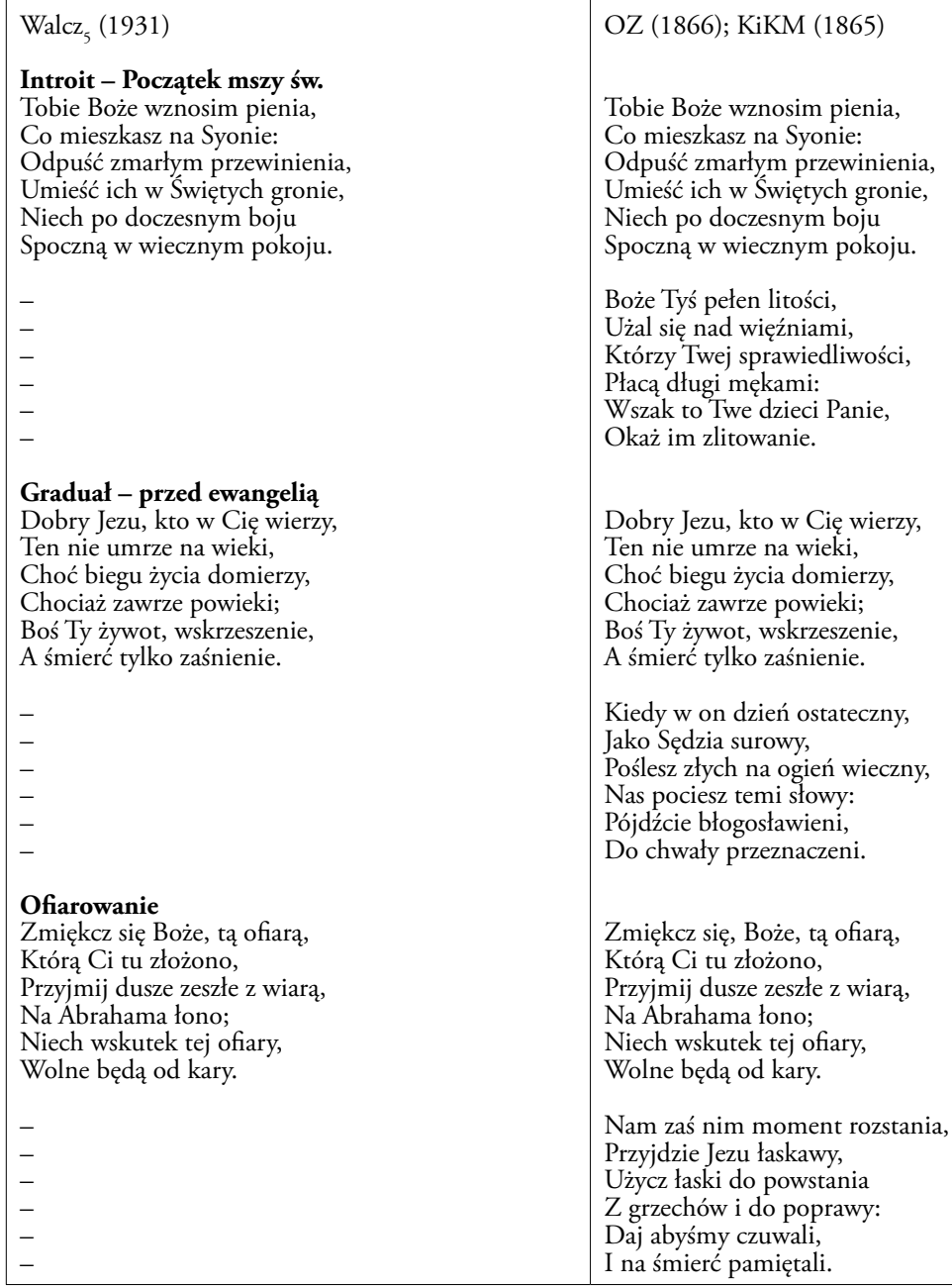


Tabela 3

\begin{tabular}{|l|l|}
\hline Walcz ${ }_{5}(1931)$ & Klon ${ }_{2}(1867)$ \\
Agnus - Baranek Boży & Agnus Dei \\
- & 1. Więc, o Jezus, mój kochany \\
- & Nie dość na tem, że śmierć, rany \\
- & Poniósł za rodzaj ludzki \\
- & Pod postacią wina, chleba \\
- & Udzielasz nam darów z Nieba \\
- & Posilasz dusze nasze. \\
& \\
1. Dobry Jezu! rzeknij słowo, & Na Komunię św. \\
Dusza moja będzie zdrową, & 1. Dobry Jezu! rzeknij słowo, \\
Wolną od ułomności: & Dusza moja będzie zdrową, \\
Wstąp, o Jezu, w serce moje, & Wolną od ułomności: \\
Niech na zawsze będzie Twoje, & Wstąp, o Jezu, w serce moje, \\
Niech w niem mieszka Twój pokój. & Niech na zawsze będzie Twoje, \\
& Niech w niem mieszka Twój pokój. \\
2. Przed Tobą, Jezu, padamy, & \\
Dzięki w pokorze składamy & 2. Przed Tobą, Jezu, padamy, \\
Za ten dar miłości Twej; & Dzięki w pokorze składamy \\
Niech ta miłość nas poświęca & Za ten dar miłości Twej; \\
I do cnoty nas zachęca, & Niech ta miłość nas poświęca \\
Co jest życiem dla duszy. & I do cnoty nas zachęca, \\
\hline
\end{tabular}

Po zestawieniu powyższych przykładów można stwierdzić, że wersje tekstowe używane przez ks. F. Walczyńskiego są uboższe, brakuje w nich strof, które były we wcześniejszych źródłach. Nasuwa się wniosek, że skoro Walczyński korzystał z najstarszych źródeł, to musiał opuścić brakujące w jego zbiorze strofy lub dostosował się do praktyki wykonawczej w swoich czasach.

Warianty tekstowe w analogicznych zwrotkach nie są zbyt liczne. Jest to spowodowane tym, że pieśni mszalne występują w stosunkowo nielicznej grupie śpiewników.

W pieśni Boże, lud Twój warianty pojawiają się w ostatnich dwóch wersach ostatniej części Ite missa est (tab. 4):

Tabela 4

\begin{tabular}{|l|l|}
\hline Walcz $_{5}(1931)$ & Przełożonym i krajowi \\
\hline Kun (1859) & Przełożonym i rządowi \\
\hline SiedlMłodz & (1908), SiedlJubil (1928) \\
\hline
\end{tabular}

W pieśni Nieogarniony warianty są znikome, polegające na zamianie jedynie pojedynczych słów: „Boś Ty sam” - „Boś Ty nam”; „co włada wojskami” - „,o włada niebami”.

Boże, Sędzio sprawiedliwy (tab. 5). 
Tabela 5

\begin{tabular}{|l|l|}
\hline Walcz5 (1931) & KiKM (1865); \\
$\begin{array}{l}\text { Graduał - Przed Ewangelją } \\
\text { Wszyscy, którzy spoczywają }\end{array}$ & $\begin{array}{l}\text { Wszyscy którzy są w grobie głos Syna Bożego } \\
\text { usłyszą i powstaną w dzień sądu strasznego } \\
\text { Sprawiedliwi i w królestwie niebieskiem osiędą, } \\
\text { Głos usłyszą i powstaną } \\
\text { W dzień Sądu ostatniego: }\end{array}$ \\
a źli na męki wieczne osądzeni będą. \\
Sprawiedliwi za swe sprawy & - \\
Chwałę wieczną posiędą, & - \\
A źli za żywot nieprawy & - \\
W piekło strąceni będą. & - \\
Wspomóżże nas, Jezu drogi, & Wspomóż nas o Jezu Zbawicielu Panie, \\
Zbawicielu nasz, Panie, & Daj chwalebne na żywot wieczny zmartwychwstanie, \\
Daj chwalebne na ów błogi & Użycz nam teraz łaski Twojej do poprawy, \\
Żywot, zmartwychwstanie: & Byśmy w dzień sądu słyszeli dekret laskawy \\
Użycz nam teraz skutecznej & - \\
Łaski Twej do poprawy, & - \\
Byśmy w on dzień trwogi wiecznej & - \\
Mieli wyrok łaskawy. & - \\
\hline
\end{tabular}

W tabeli 5 widzimy zmianę rozmiarów wersów. Ksiądz Walczyński posłużył się strofą o strukturze wersów: $8+7+8+7$, natomiast w zbiorze KiKM (1865) widzimy schemat miar następujący: $13+13+14+13$ i $12+13+13+13$. Jest to rzadko spotykane przekształcenie, które wiąże się z nieco zmienionym tekstem.

\section{Struktura tekstów}

Tekst jako jeden dwóch elementów (oprócz melodii) tworzących pieśn jest bardzo istotny. Musi on z melodią ściśle współdziałać. Oba te elementy wzajemnie się kształtują i świadczą o całości wartości artystycznej dzieła. Poniżej w sposób ogólny zostanie ukazana struktura tekstów, którą określają: metryka, rymy oraz strofika.

W badanym materiale pieśniowym wymienione elementy są kształtowane w sposób zróżnicowany. Strofa ośmiowersowa występuje tylko w dwóch pieśniach (Boże, lud twój oraz Boże, Sędzio sprawiedliwy). W pierwszej jest izosylabiczna, ujęta ośmiozgłoskowcem, co udowadnia zdanie Zdzisławy Kopczyńskiej, że najczęstszym komponentem strofy ośmiowersowej jest ośmiozgłoskowiec ${ }^{54}$. Znajdujemy kilka wyjątków (w Credo i na Podniesienie), gdzie miara zmienia się na dziewięciozgłoskowiec, ale wydaje się, że nie mają one wpływu na całość struktury poetyki. Elementem scalającym są rymy naprzemienne, o schemacie: ababcdcd. Ten rodzaj ukształtowania wiązanego czterema rymami, pojedynczo przeplatanymi,

\footnotetext{
54 Z. Kopczyńska, Strofa ośmiowersowa, w: Strofika, red. M. R. Mayenowa, Wrocław-Warszawa-Kraków 1964, s. 297.
} 
składa się jakby z dwu czterowierszy tak rymowanych ${ }^{55}$. W drugiej strofa jest heterosylabiczna, ujęta w schemacie miar na przemian ośmio- i siedmiozgłoskowych: $8+7+8+7+8+7+8+7$ (z pojedynczymi wyjątkami). Rymy, podobnie jak w pierwszej, są naprzemienne: ababcdcd.

Strofa siedmiowersowa pojawia się tylko w jednej pieśni (Przedziwna Matko), jest heterosylabiczna, o stałym schemacie miar, powtarzającym się konsekwentnie w każdej zwrotce: $11+8+11+8+11+11+8$ (w kilku przypadkach ostatni wers strofy liczy siedem zgłosek). Ten rodzaj strofy występował często w poezji melicznej, jak liryka mieszczańska czy pieśni kościelne. Spośród wielu układów rymowych najczęściej spotyka się w tym typie strofy czterowiersz z tercetem ${ }^{56}$. Taki typ układu znajdujemy w badanej pieśni Przedziwna Matko. Występują tu, w większości zwrotek, rymy naprzemienne i parzyste: ababccx, gdzie ostatni wers nie jest objęty wiązaniem rymowym.

Strofa sześciowersowa, o różnych miarach wersów, występuje w czterech pieśniach. Generalnie jest ona, po czterowersowych, najczęstszą strofą w polskiej poezji. Dwie pieśni posiadają taki sam stały schemat miar wersów, mianowicie: $8+8+7+8+8+7$ (Przed tronem Twym upadamy oraz Panie! Stwórco nieba, ziemi), zaś jedna w oparciu o te same miary posiada schemat nieco zmieniony: $8+7+8+7+7+7$ (Tobie, Boże, wznosim pienia). Czwarta pieśń zawiera natomiast inny schemat miar wersów: $14+14+8+8+8+8$ (z kilkoma wyjątkami). W badanym materiale pieśni o strofach sześciowersowych występują trzy typy układów rymowych, bowiem dwie pierwsze posiadają ten sam układ: aaxbbx, z dwoma rymami przylegającymi, przedzielonymi wersami bez rymów. W trzeciej pieśni znajdujemy rymy naprzemienne i przylegające: ababcc, zaś czwarta pieśń cechuje się układem strofy o trzech rymach parzystych: aabbcc, występującym w układzie poza sześciowersowym niezbyt często w polskiej poezji ${ }^{57}$.

Najbardziej popularna w polskiej poezji strofa czterowersowa w badanym materiale występuje tylko w jednej pieśni (Nieogarniony). Jest ona izosylabiczna, ujęta jedenastozgłoskowcem, wiązana rymami naprzemiennymi: abab. Należy nadmienić, iż w omówionym materiale występują głównie i niemal wyłącznie rymy żeńskie, dokładne.

\section{Melodie}

Warstwa muzyczna, oprócz tekstowej, jest także ważnym czynnikiem kształtującym formę pieśni. W badanym materiale melodie są autorstwa ks. Walczyń-

\footnotetext{
Z. Kopczyńska, Strofa ośmiowersowa, dz. cyt., s. 290-291.

6 A. Goreniowa, Strofa siedmiowersowa, w: Strofika, dz. cyt., s. 273-274.

57 Z. Kopczyńska, Strofa sześciowersowa, w: Strofika, dz. cyt., s. 240.
} 
skiego, zaś teksty przejęte z funkcjonujących już pieśni, dlatego w tytule publikacji czytamy: Nowe melodie do starych pieśni mszalnych... ${ }^{58}$. Melodie opracowane są w układzie dwugłosowym, ujęte w dur-moll, przeważnie w tonacjach do trzech znaków przy kluczu. Ksiądz Walczyński, jak to już powiedziano, był autodydaktą, dlatego zapewne poruszał się właśnie w tym zakresie tonacji.

\section{Cechy formy melodycznej}

Wśród cech formy melodycznej na uwagę zasługuje fakt, iż wszystkie pieśni są zawarte w ambitusie szerokim, czyli oktawy lub większym, co wpisuje badane pieśni w ogólne tendencje rozwojowe formy pieśni. Przykładem może być pieśń Przedziwna Matko, w której ambitus sięga 10> $\left(\mathrm{d}^{1}-\mathrm{f}^{2}\right)$ (przykł. 1).

Przykład 1

Walcz4 (1931)

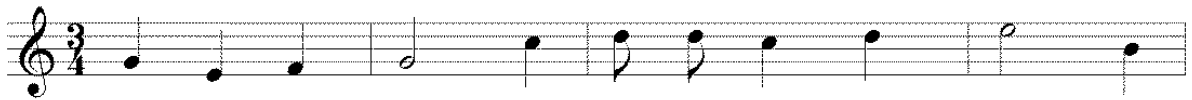

Prze - dzi - wna Ma - tko Sto - wa wcie - lo - ne - go,

$\mathrm{Kie}-\mathrm{dy}$ pa - mią - tkę $\mathrm{Na}-\mathrm{ro}-\mathrm{dze}-\mathrm{nia}$ Twe - go*)
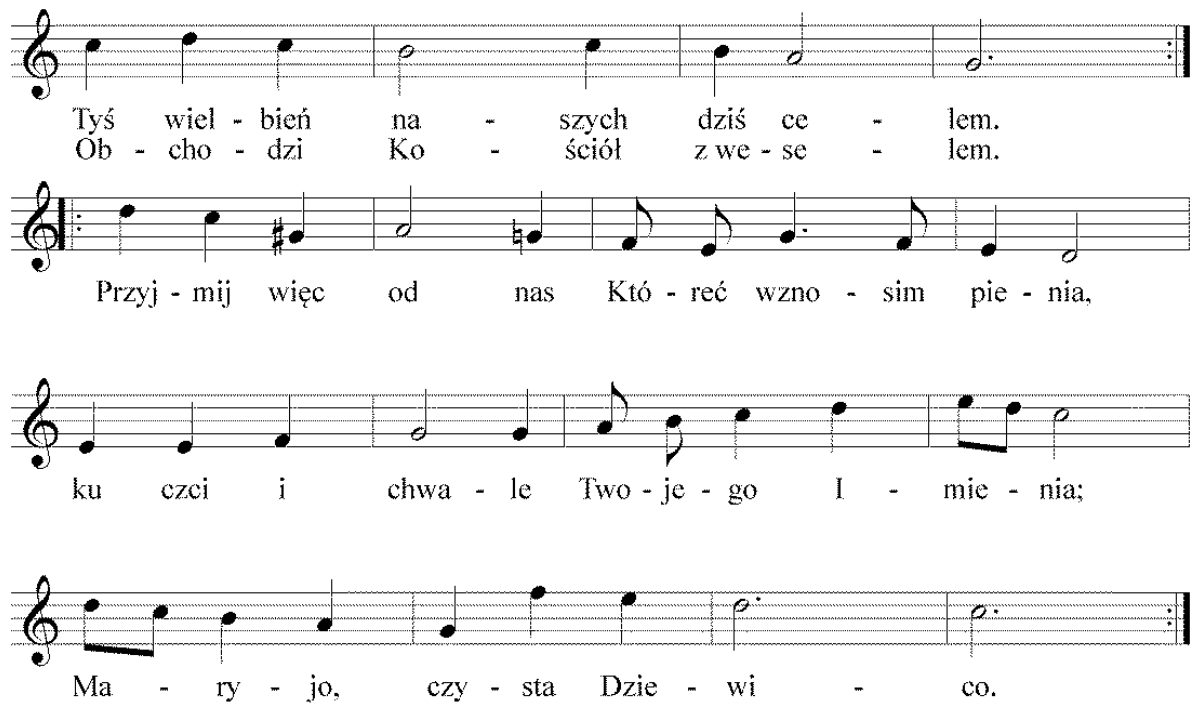

*) Wniebowziçcia Twego.

Poczecia lwojego

Zwiastowania Twego itp.

58 Walcz4 (1931). 
Pod względem kierunku linii melodycznej dominuje ruch łukowy i falisty, co świadczy o istnieniu jednego punktu kulminacyjnego w środku melodii - w pierwszym przypadku, lub o kilku kulminacjach - w drugim. Przykładem kierunku łukowego jest pieśń Boże, Sędzio sprawiedliwy, w której punkt kulminacyjny znajduje się w środkowej części melodii (przykł. 2).

Przykład 2

WalczA (1931)

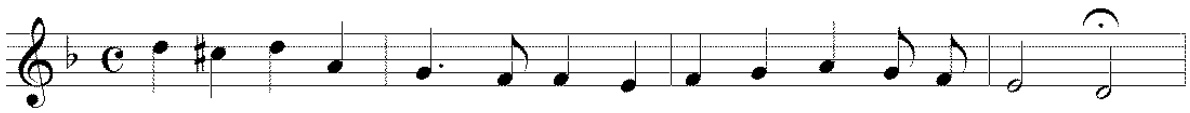

Bo-że, Sę-dzio spra - wie-dli - wy, a - słysz na - sze wo - ła - nie;

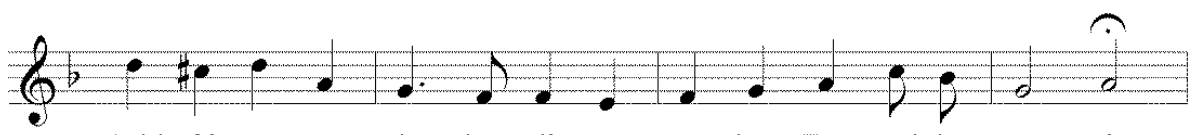

Ach! Oj-cze nasz, do - bro - tli - wy, po - kaz Twe zmi-1o - wa - nie

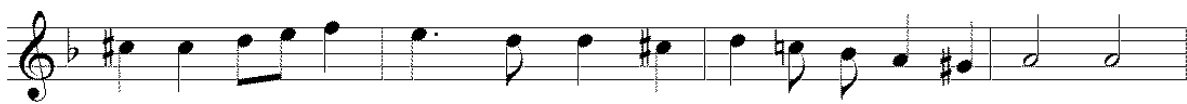

nad du-sza - mi wier - nych, zmar-łych, któ-re za swo-je grze - chy

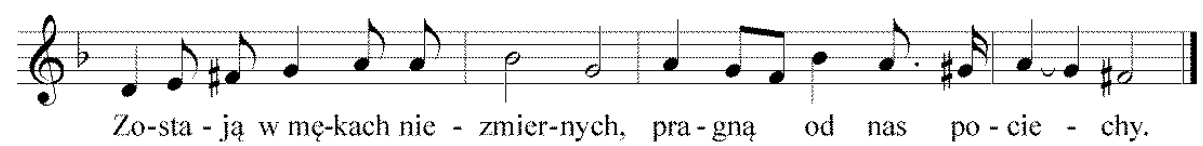

Pod względem interwałowym należy wymienić jako dominujący ruch sekundowy, decydujący o kantylenowym, śpiewnym charakterze melodii (przykł. 3). Ponadto zdarzają się też interwały charakterystyczne, jak 4cz, 5cz, 7m. Umieszczone są one w początkowych lub końcowych frazach melodycznych. Repetycje występują bardzo rzadko i tylko w niektórych pieśniach. 
Przykład 3

Walcz4 (1931)
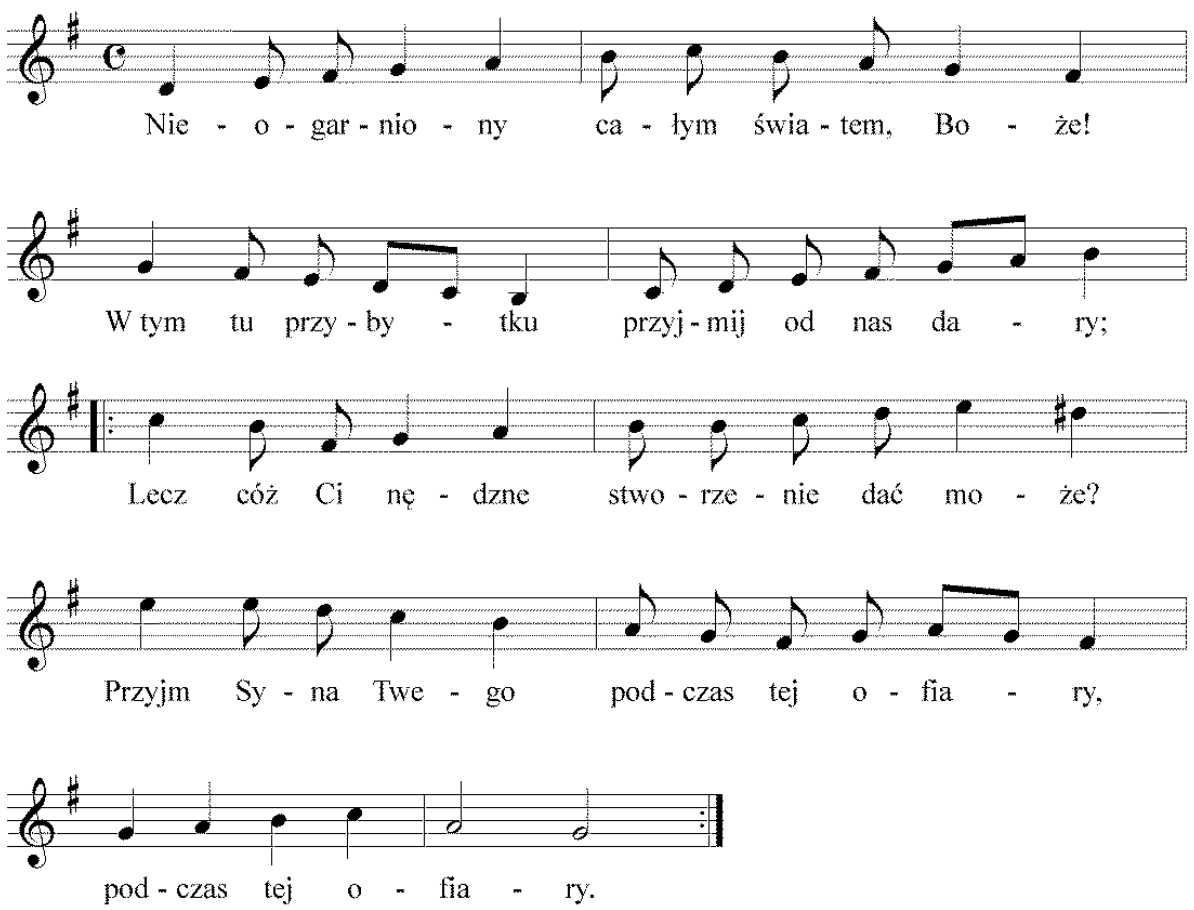

\section{Architektonika}

Właściwości formy - w tym przypadku formy pieśni - wyrażające się w upostaciowaniu zewnętrznym oraz układzie sił integrujących formę świadczą o jej architektonice. W znacznej zależności od budowy wersów i ich wewnętrznego rozczłonkowania oraz od liczby wersów składających się na zwrotkę tekstową kształtuje się forma i struktura zwrotki muzycznej, w której można wyróżnić różnych rozmiarów frazy, zdania i okresy ${ }^{59}$.

W badanym materiale pieśni mszalnych spotykamy struktury dwu-i trzyczęściowe. Zgodnie z ogólną tendencją tych pierwszych jest więcej. Są podstawą struktur w sześciu pieśniach. Ponadto ich cechą jest zróżnicowanie części: AB, co znowu potwierdza ogólną tendencję w polskich pieśniach religijnych. Jedynie ta forma dwuczęściowości pojawia się w badanym materiale. Zróżnicowane są natomiast ich wewnętrzne powiązania; jest ich kilka. W trzech pieśniach występuje struktura $\left(\mathrm{aa}_{1}\right)(\mathrm{bc})$, gdzie w poprzedniku fraza „a” jest powtórzona z niewielką zmianą

59 B. Bartkowski, Polskie śpiewy religijne w żywej tradycji. Style i formy, Kraków 1987, s. 154. 
w kadencji, natomiast następnik wykorzystuje dwie różne frazy melodyczne. Są to Boże, lud Twój $j^{60}$, W tej światyni zgromadzeni ${ }^{61}$ oraz Boże, Sędzio sprawiedliwy ${ }^{62}$. W pierwszej (Boże, lud Twój) widzimy melodię 16-taktową, w której poprzednik i następnik liczą po osiem taktów i dzielą się, każdy z nich, na dwie frazy czterotaktowe, obejmujące pary kolejnych wersów strofy ośmiowersowej, izosylabicznej, ujętej ośmiozgłoskowcem. Podobna sytuacja ma miejsce w drugiej pieśni ( $W$ tej świątyni zgromadzeni) o takiej samej długości i analogicznym podziale, jednakże z ciekawym podziałem tekstu, co potem kompozytor wykorzystał przy kształtowaniu melodii. Mamy tu do czynienia ze strofą heterosylabiczną, dosyć radykalnie zróżnicowaną. Pierwsze dwa wersy są 14-zgłoskowe, zaś pozostałe cztery ujęte ośmiozgłoskowcem. Stąd kompozytor w poprzedniku wykorzystał tylko dwa pierwsze wersy, ale o dużych rozmiarach, zaś w następniku pozostałe cztery. Melodia zachowała symetrię, mimo iż tekst nie. W trzeciej pieśni, Boże, Sędzio sprawiedliwy, struktura jest identyczna jak w pierwszej, mimo strofy heterosylabicznej (ośmiowersowa, naprzemiennie ośmio- i siedmiozgłoskowiec), podział wewnętrzny jest symetryczny zarówno w melodii, jak i w tekście.

Zaburzoną symetrię posiada pieśń mszalna Nieogarniony ${ }^{63}$, w której melodia 10-taktowa obejmuje strofę czterowersową, poprzednik jest czterotaktowy i dzieli się na dwie frazy dwutaktowe, następnik zaś liczy sześć taktów, w których cztery obejmują dwa wersy, analogiczne jak w poprzedniku, zaś dwa są opatrzone powtórzonym fragmentem ostatniego wersu. Stąd rozszerzenie następnika. Schemat wewnętrznych powiązań wygląda następująco: $(\mathrm{ab})(\mathrm{cd})$ e.

Dwie pieśni (Panie! Stwórco nieba, ziemi ${ }^{64}$ oraz Przed tronem Twym upadamy ${ }^{65}$ ), także o budowie dwuczęściowej, posiadają inny schemat wewnętrznych powiązań. Wspólną cechą jest to, iż każdy z dwóch członów dzieli się na trzy frazy dwutaktowe obejmujące kolejne wersy strofy sześciowersowej. Obie pieśni posiadają strofy heterosylabiczne o stałym schemacie rozmiarów wersów: $8+8+7+8+8+7$. Różni je jedynie ukształtowanie fraz melodycznych. Pierwsza wykorzystuje zróżnicowane frazy: (abc) (def), druga zaś w poprzedniku powtarza frazę „a”, zaś w następniku frazę „c”: (aab) (ccd), przez co utwierdza swoją zwartość.

\footnotetext{
60 Walcz4 (1931), s. 1.

61 Walcz4 (1931), s. 5.

62 Walcz4 (1931), s. 7.

63 Walcz4 (1931), s. 2.

64 Walcz4 (1931), s. 3.

65 Walcz4 (1931), s. 4.
} 
Formy trzyczęściowe występują $\mathrm{w}$ dwóch $\mathrm{z}$ badanych pieśni, mianowicie: Tobie, Boże, wznosim pienia ${ }^{66}$ oraz Przedziwna Matko ${ }^{67}$. Wykazują on wspólny typ struktury: $\mathrm{AAB}$, w którym pierwsze dwie części są takie same, a trzecia inna. Co ciekawe, struktura wewnętrznych powiązań jest także prawie taka sama. W pierwszej pieśni (Tobie, Boże, wznosim pienia) melodia 12-taktowa dzieli się na trzy człony czterotaktowe, każdy z nich dzieli się na dwie frazy dwutaktowe obejmujące kolejne wersy sześciowersowej strofy, heterosylabicznej, o miarach wersów ośmioi siedmiozgłoskowych. Schemat wewnętrznych powiązań jawi się następująco: (ab) (ab) (cd). W drugiej pieśni (Przedziwna Matko) melodia jest 28-taktowa i dzieli się na trzy części, każda z nich ośmiotaktowa, oraz czterotaktowy dodatek w trzecim członie. Obejmuje ona strofę siedmiowersową, heterosylabiczną, o stałym schemacie miar wersów: $11+8+11+8+11+11+8$, gdzie kompozytor wykorzystał do trzech członów sześć wersów, a siódmy opatrzył dodatkową melodią, jak już wspomniano - czterotaktową. W ten sposób symetria została zaburzona, a schemat wewnętrznych powiązań jest następujący: (ab) (ab) (cd) e.

Podsumowując, należy stwierdzić, iż działalność muzyczna ks. Franciszka Walczyńskiego stanowi ważny wkład w dziedzinę kultury muzycznej Kościoła zarówno tarnowskiego, jak i polskiego. Pieśni mszalne będące przedmiotem badań są tego najtrafniejszym przykładem. Dostrzegamy w nich pewne continuum z dotychczasowym skarbcem muzycznym w Kościele polskim, gdyż teksty zostały przejęte z już funkcjonujących śpiewów, zaś nowością są melodie ułożone przez ks. Walczyńskiego. Pod względem treści możemy powiedzieć, że „pieśni mszalne z II poł. XVIII i początku XIX wieku odznaczają się dydaktyzmem, w którym zawierało się nauczanie i umoralnianie, oraz teocentryzmem podkreślającym wielkość Boga i przepaść między Bogiem a człowiekiem. Uprzytamnianie nędzy ludzkiej miało skłaniać do upokorzenia i dobrego życia, za które obiecywano nagrodę, a ukazywanie wielkości i dobroci Bożej do zaufania Opatrzności Bożej i przyjmowania każdego losu z ręki Boga" ${ }^{68}$. Są to cykle liczące przeważnie od dziewięciu do sześciu części. Warianty tekstowe są nieliczne. Struktura tekstów oparta wyłącznie na budowie stroficznej wykorzystuje zwrotki od ośmio-, siedmio-, sześcio- i w jednej pieśni czterowersowe. Są one w przewadze hetrosylabiczne, wiązane rymami żeńskimi dokładnymi, układającymi się naprzemiennie oraz rzadziej - przylegająco.

66 Walcz4 (1931), s. 8.

67 Walcz4 (1931), s. 6.

68 B. Bielawska, Polska pieśń..., dz. cyt., s. 156. 
Pod względem muzycznym pieśni mszalne zawarte w badanym zbiorze ks. Walczyńskiego prezentują układy dwu- i trzyczęściowe, oparte o harmonikę dur-moll, formę melodyczną cechującą się szerokim zakresem ambitusu, kierunkiem łukowym i falistym, pochodach sekundowych. Wszystkie te cechy ukazują wartość artystyczną twórczości muzycznej ks. Walczyńskiego, będącej świadectwem religijnej kultury muzycznej Kościoła katolickiego w Polsce w XIX i w początkach XX w.

\section{Streszczenie}

Pieśni mszalne ks. Franciszka Walczyńskiego

Pieśni mszalne ks. Franciszka Walczyńskiego są kontynuacją tego gatunku istniejącego od drugiej połowy XVIII w. Kompozytor przejął wybrane teksty z pieśni już istniejących i opatrzył je nowymi melodiami. Pieśni mszalne w twórczości Walczyńskiego to cykle liczące przeważnie od dziewięciu do sześciu części. Warianty tekstowe są nieliczne. Struktura tekstów oparta wyłącznie na budowie stroficznej wykorzystuje zwrotki od ośmio-, siedmio-, sześcio- i w jednej pieśni czterowersowe. Są one w przewadze hetrosylabiczne, wiązane rymami żeńskimi dokładnymi, układającymi się naprzemiennie oraz rzadziej przylegająco.

Pod względem muzycznym pieśni mszalne zawarte w badanym zbiorze ks. Walczyńskiego prezentują układy dwu- i trzyczęściowe, oparte o harmonikę dur-moll, formę melodyczną cechującą się szerokim zakresem ambitusu, kierunkiem łukowym i falistym, interwałami sekundowymi. Wszystkie te cechy ukazują wartość artystyczną twórczości muzycznej ks. Walczyńskiego, będącej świadectwem religijnej kultury muzycznej Kościoła katolickiego w Polsce w XIX i w początkach XX w.

\section{Summary}

The Mass songs of Rev. Francis Walczyński

Mass songs of Rev. Francis Walczyński are the continuation of this type, existing since the second half of 18 th century. The composer took over the selected lyrics from the songs that was already in existence and gave them new melodies. Mass Songs in Walczyński's 
works are cycles counting mostly from 9 to 6 parts. Text variants are few. The structure of texts based exclusively on strophic structure uses stanza with 8th, 7th, 6th and in one song 4-verses. They are predominantly heterosyllabic, bound by feminine perfect rhymes, intermittently alternating and less adherent.

In terms of music, the Mass songs contained in the studied set of Fr. Walczyński presents two- and three-part layout, based on the major-minor harmonic function, a melodic form characterized by a wide range of ambitus, curved and wavy direction, and second intervals.

All these features show the artistic value of the music work of Rev. Walczyński, which is a testimony of the religious musical culture of the Catholic Church in Poland in the 19 th and in the early 20 th centuries.

Stowa kluczowe: polska pieśń mszalna, poetyka, architektonika, cechy formy muzycznej, wewnętrzne powiązania

Keywords: Polish Mass song, poetics, architectonics, features of musical form, internal links

\section{Bibliografia}

\section{Źródta}

[Folwarski P.], Śpiewnik „Qui cantat bis orat”, Kraków 1802.

Cancional Piosnek rozmaitych, Staniątki 1586.

Kancyonat i ksiażka modlitewna na caty rok. Do nabożeństwa kościelnego i domowego, druk i nakł. K. Prochaska, Cieszyn 1865.

Ksiażka modlitewna i kancjonat, Opole 1830.

Mazurowski J., Melodie do zbioru pieśni nabożnych katolickich do użytku kościelnego. Utożone do grania na organach i śpiewania na cztery gtosy, Pelplin 1871.

Ottarz ztoty czyli zbiór nabożeństwa dla chrześcian katolików z przydatkiem pieśni nabożnych dla użytku wiernych utożony, druk i nakł. J. Cotta, Warszawa 1866.

Pieśni kościelne dla mtodzieży szkót gimnazyalnych [...] wydat Tomasz Kunzek, Lwów 1859.

Praca codzienna, coroczna i catożywotna każdego chrzescianina katolickiego; albo: ksiażka modlitewna $i$ kancyonat dla katolików, $z$ różnych ksiażek modlitewnych i śpiewników zebrana, Cieszyn 1858.

Raszek W., Kancjonat muzyki kościelnej, Warszawa 1825.

Siedlecki J., Śpiewnik kościelny. Wydanie jubileuszowe (1978-1928), oprac. W. Świerczek, B. Wallek-Walewskiego, Kraków [1928]. 
Szczeble do nieba, czyli zbiór pieśni z melodyjami w Kościele rzymsko-katolickim od najdawniejszych czasów używanych, uskuteczniony przez Teofila Klonowskiego nauczyciela przy Król. katol. naucz. Seminarium w Poznaniu, t. 1, Poznań 1867.

Śpiewniczek zawierający pieśni kościelne z melodyami dla u̇̇ytku mtodzieży szkolnej przez x. J. Siedleckiego zebrany a przez Wysokq c.k. Rade Szkolna krajowa uchwata z dnia 14 lipca 1880 L. 556 dla szkót ludowych, pospolitych i wydziatowych przeznaczony, Kraków 1908.

Śpiewnik Kościelny czyli pieśni nabożne z melodyjami w kościele katolickim używane a dla wygody kościotów parafialnych przez X. M. M. Mioduszewskiego Zgrom. XX. Miss. zebrane, Kraków [1838]; oraz Dodatki: 1842, 1849, 1853.

Śpiewnik kościelny dla mtodzieży szkolnej z polecenia przewielebnego Księdza St. O. D. i P. W. wydany, Bochnia 1863.

Śpiewnik kościelny dla mtodzieży szkolnej, czcionkami K. Budweisera, Kraków 1861.

Śpiewy kościelne dla mtodzieży, Wadowice 1858.

Śpiewy nabożne dla użytku katolików archidyecezyi gnieźnieńskiej i poznańskiej, zebr. i wyd. ks. T. Kiliński, Poznań 1862.

Walczyński F., Nowe melodje do starych pieśni mszalnych w uktadzie dwugtosowym dla użytku mtodzieży szkolnej i chórów parafialnych, Tarnów 1931.

Walczyński F., Tekst pieśni mszalnych dla u̇̇ytku mtodzieży szkolnej i chórów parafialnych, Tarnów 1931.

\section{Opracowania}

Bartkowski B., Polskie śpiewy religijne w żywej tradycji. Style i formy, Kraków 1987.

Bielawska B., Polska pieśn mszalna do 1914 roku, w: Studia z dziejów liturgii w Polsce, t. 3 , red. W. Schenk, Lublin 1980, s. 117-204.

Feicht H., Studia nad muzyka polskiego średniowiecza, Kraków 1975.

Garnczarski S., Początki polskiej pieśni kościelnej i jej tematyka, „Tarnowskie Studia Teologiczne" 35 (2016) nr 1, s. 177-187.

Garnczarski S., Polska pieśn adwentowa w drukach od XVII do XX wieku, cz. 1, Tarnów 2014.

Goreniowa A., Strofa siedmiowersowa, w: Strofika, red. M. R. Mayenowa, Wrocław-Warszawa-Kraków 1964, s. 273-289.

Kopczyńska Z., Strofa ośmiowersowa, w: Strofika, red. M. R. Mayenowa, Wrocław-Warszawa-Kraków 1964, s. 290-341.

Kopczyńska Z., Strofa sześciowersowa, w: Strofika, red. M. R. Mayenowa, Wrocław-Warszawa-Kraków 1964, s. 202-272.

Marciniak R., Muszyński M., Wiesiołowski J., Katalog rękopisów staropolskich Biblioteki Kórnickiej XVI-XVIII w., t. 1, Wrocław 1971. 
Nowak A., Walczyński Franciszek, w: Stownik polskich teologów katolickich 1918-1981, t. 6, red. L. Grzebień, Warszawa 1983, s. 362-371.

Nowak-Romanowicz A., Muzyka religijna, w: Klasycyzm 1750-1830. Historia muzyki polskiej, t. 4, red. S. Sutkowski, Warszawa 1995.

Orzech W., Dziatalność kościelno-muzyczna ks. Infutata Franciszka Walczyńskiego, Odbitka z dwumiesięcznika „Chór Parafialny”, Przemyśl 1938, s. 5-16. 